\title{
Successful Tongan Students in New Zealand Secondary Schools: Default or Design?
}

\author{
Ingrid Frengley-Vaipuna \\ Patea Area School, South Taranaki \\ Dr Lesieli Kupu-MacIntyre and Associate Professor Tracy Riley \\ Massey University
}

\begin{abstract}
This article outlines the use of Gagne's (2008) Differentiated Model of Giftedness and Talent (DMGT) as applied to Tongan secondary school students in New Zealand. Two case studies of Tongan young women are shared with a particular emphasis on the influence of catalysts, the chance factor, and developmental processes upon the development of their gifts to talents. The article explains the Tongan way, a conceptual map for developing better understandings of Tongan gifted and talented students in New Zealand. The article concludes that the Differentiated Model of Giftedness and Talent is a framework teachers can use to explore giftedness with Pasifika families, communities, and students to assist in better understanding their special abilities, qualities, and needs.
\end{abstract}

\section{Research paper}

Keywords: Gagne, gifted and talented, Tongan

\section{SUCCESSFUL TONGAN STUDENTS IN NEW ZEALAND SECONDARY SCHOOLS: DEFAULT OR DESIGN?}

Tongans have migrated mostly to New Zealand, Australia and the United States, with Tongan populations tending to be concentrated in particular cities and towns within these countries. A complex network of connections exists between Tongans in these places and in Tonga, including the practice of sending remittances and the extensive use of online communication. Few Tongans ever completely lose their connections - emotional, familial, economic, religious, and otherwise - to their homeland; they remain between two shores. Often the primary motivation for migration is to help the family. The idea of 'family' encompasses a complex set of rights and obligations of Tongan kinship as well as the deep emotional connections between kin (Morton-Lee, 2003).

The largest group of Tongans living overseas is in New Zealand where they constitute $18 \%$ of the Pasifika population (Statistics, NZ, 2007).
According to the 2001 census, $80 \%$ of the 40,716 Tongans in New Zealand (Statistics, NZ, 2007) live in Auckland, the biggest Polynesian city in the world. Just over half of Tongan people in New Zealand are New Zealand born and the youthful population is rapidly increasing. Immigration to New Zealand is driven by educational and economic aspirations and, although some return to Tonga, most have established families in New Zealand, adapting their traditions of church life, kinship bonds and child rearing to the new environment (Tau'akipulu, 2000). A third of Tongan families in New Zealand include the nuclear family, a grandparent and members of the kāinga (extended family). Ninety-two percent of Tongans in New Zealand are affiliated with a religious group and are generally intensively involved in the church which is the mainstay of Tongan community life.

\section{Cultural Concepts}

Tongan students in New Zealand are very likely to reflect the beliefs of their parents and kāinga (extended family). These may include definite views about social structure, learning and teaching, as well as social values. Tongans have particular traditional views about the hierarchical structure of society which influence all activities (Figure 1). Rank is fixed at birth and the most fundamental distinction is between 'eiki (chief/ noble) and tu'a (commoner). Tu'i (paramount chief, royalty) and matāpule (chief's ceremonial attendants) are actually separate categories but are usually encompassed within the general category hou'eiki (chiefly people). Over time, especially since the emergence of an educated middle class of commoners and church dignitaries, the power accorded to each rank has altered significantly. However, there is still a clear distinction between hou'eiki and $t u^{\prime}$ a that affects people's everyday lives (Morton, 1996). 


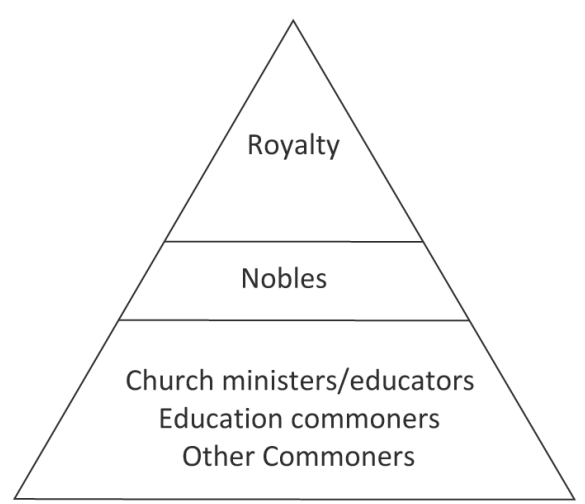

Figure 1. Rank in Tonga: A simple view.

Cutting across the ranking system is social differentiation based on status. In any given context, a person's status is relative to that of whomever else is present. It is primarily determined by seniority (chronological or genealogical), gender and kinship relations. Another, more flexibly determined factor, is reputation which can be enhanced by education, wealth, generosity, and involvement in church activities.

A poto person (one who is clever, wise, capable, able and socially-competent) must be aware of the complexities of rank and status, including the current tensions arising from contact with other cultures. The following definition would be considered within that social context. Morton explains that becoming poto entails learning the skills necessary for daily life and acquiring a formal education, but most essentially it entails developing appropriate anga (habit; custom; nature; quality; character; behaviour; conduct). One's anga should be totonu (right, proper), fe'unga (befitting, suitable) and lelei (good). Becoming poto also involves being able to match behaviour to context - knowing what to do, being able to do it, knowing when to do it and doing it well ${ }^{1}$. Being poto means both learning the rules and learning how to manipulate them to one's advantage. Like the English term 'clever', the meaning of poto can shade into 'cunning', 'crafty' or 'astute'. Because protecting and enhancing the reputation of self and family, and avoiding fakamā (shame), are central motives for proper behaviour in Tonga, the need for children to develop proper and become poto tends to be explained in terms of the importance of other people's opinions and expectations.

To be poto is a highly valued, ideal end point of socialisation and, like Gagne's (2002) talent development process, perceived as a process of achievement and success, a movement from vale (foolish, silly, ignorant, immature, unskilled, incapable, incompetent), which is often considered the natural state of children, although individuals of any age can be called vale or anga vale when they have behaved foolishly or been socially inept. Thus, giftedness in Tonga includes the following:

- possession of knowledge that is worthwhile to society and therefore acknowledged by others

- ability to practise and pass that knowledge on to others

- social status within a group

- spiritual/mystical elements which give power/influence.

This concept of giftedness encompasses many aspects of 'ulungaanga faka-Tonga (the Tongan way) and may or may not include being 'atamaivave (quick minded, quick thinking).

1 The term fakapotopoto is used for people who are wise in respecting the social nuances in particular situations.

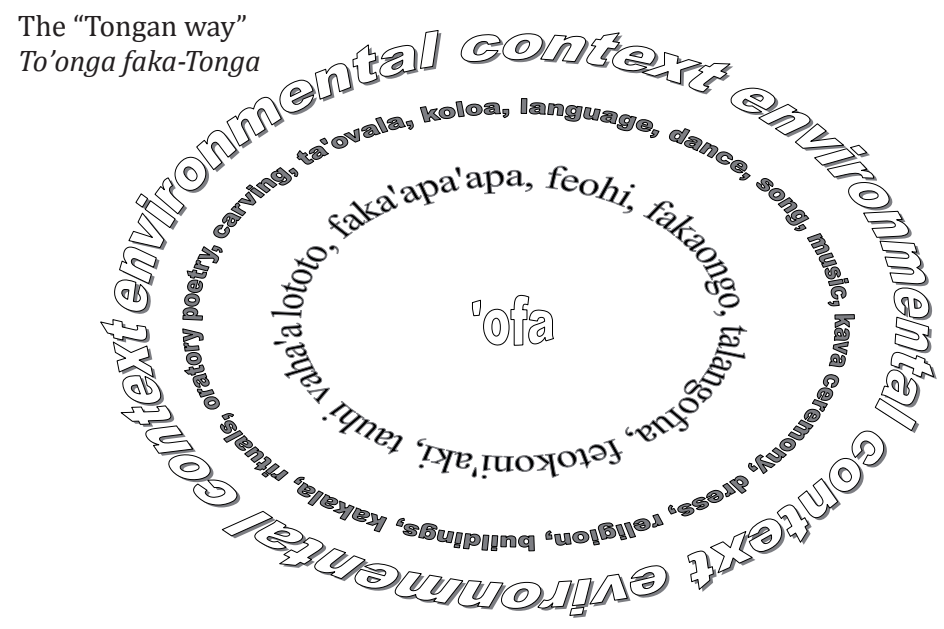

Figure 2. The Tongan Way To'onga faka-Tonga. 


\section{The Tongan Way}

The world of the Tongan child in New Zealand, or elsewhere, is deeply affected by 'ulungaanga fakaTonga. In order for educators to positively enable talent development of Tongan students,some understanding of this epistemological viewpoint is needed. In this section, we explain the Tongan Way is exemplified by Seini and Julia (pseudonyms), students who were the subjects of research into gifted and talented Tongan students in New Zealand (Frengley-Vaipuna, 2007). At the time of the research, both young women were at faith-based schools in Year 13, prefects, accomplished orators and leaders of various sporting, cultural and musical school groups. Seini was born in New Zealand and had parents who were both educated to tertiary level. Julia had come to New Zealand when she was four and her parents worked in the service industry.

Figure 2 provides a conceptual map which can be used to help educators understand gifted and talented Tongan students living in New Zealand. At the outer edge lies the environmental context, and if this outer layer changes, other layers will change in response to the altered life experiences. Each person's sense of the Tongan way will be unique and will alter during their lifetime. Traditions or customs are generated empirically, being those ways of doing things, beliefs held etc. which we find to work in our particular geographic or social environment. Customs are generally environmentspecific. Cultural traditions can cease to work in new or changed environments (Helu, 1999a).

'Ulungaanga faka-Tonga/to'onga faka-Tonga or 'the Tongan way' is a complex socialisation process. Futa Helu (1999b; 1999c), long time director of Atenisi University, defines cultural traditions as those forms of behaviour such as activities, beliefs, values and ideals, that change so slowly they give the impression of not changing at all and are so because they are promoted throughout society. He maintains that the complete set of such forms of behaviour for a given social group or society is the culture of that group. Morton-Lee (2003) reports that many Tongans assert that to be 'really' Tongan, a person must have not only Tongan ancestors, but also a knowledge of 'ulungaanga faka-Tonga, or the Tongan Way. She explains that this concept encompasses all values, beliefs, and practices that are regarded as elements of Tongan culture and tradition. However, unlike Helu, she believes that such a broad definition is open to interpretation and is constantly under negotiation and reconstruction. She does not regard competence in Tongan language as essential. Furthermore, Morton-Lee (2003) believes that any attempt to list and measure the criteria that define Tongan identity would be futile as each individual has their own definition of that identity shaped by their social/ cultural background and life experiences.

For instance, Seini and Julia are both proud to be Tongan yet coming from quite different backgrounds, have quite different exposure to, and understanding of, 'ulungaanga faka-Tonga. However, both girls crave leadership roles and in order to be seen as poto by other Tongans, and therefore have influence in their communities, they need to have some understanding of certain elements that are widely regarded as essentially Tongan, even though some of these elements are contested and subject to transformation (MortonLee, 2003). These elements are shown in the inner rings of Figure 2 and explained below.

Feohi refers to ideals of closeness and togetherness (Morton, 1996). This entails the interactions with immediate and extended family and the maintenance of kinship ties which promote an understanding of the hierarchical roles within the kāinga. This will also involve knowledge of language which brings a deeper understanding of 'ulungaanga faka-Tonga and easy access to Tongan community functions and events. Within families, each member has clearly defined roles and obligations based on fetokoni'aki (the concept of reciprocity) and depending on their birth order, status, education level and access to resources (often aligned with opportunities afforded through migration). For example, giving a prize won at school immediately to the paternal aunt publically at the prizegiving, honours her status in the family. The individual is less important than the family.

Faka'apa'apa or respect is a defining feature of all social relations which involves deference to those of higher status. It can be broadly seen as general good manners or as acknowledging tapu (taboos). An example is the traditional respect children should show their father by not touching his head, using his personal belongings that touch his body (clothes, gloves, shoes etc.), sharing his food or drink or being overly familiar with him. There are many tapu associated with brother/ sister relationships (including all cousins, second cousins and relations of the same generation). In Seini's boarding school these cultural traditions were used to define the relationships between male and female students although she felt the boys at the school were not as respectful as they should be. However, her friend Lopeti explained respect as "the way you act in front of your Tongan sisters and that 'cos that's the way I was brought up. I wasn't allowed to watch TV with my sisters and that kind of...all those other stuff..." (FrengleyVaipuna, personal communication, 2005). That "stuff" includes not swearing, any kind of sexual references or banter, going into your sisters' rooms, 
girls not wearing shorts or other revealing clothes around their brothers, viewing sexuality (including kissing) in the media. These taboos (tapu) are often broken inadvertently in New Zealand high schools. Some Tongan families in New Zealand have relaxed these taboos. As Julia said of her parents, "they've just sort of adapted to both worlds," (Frengley-Vaipuna, personal communication, 2005) and many Tongan parents have made many such adaptations to the Tongan way.

Talangofua is best described as obedience, listening properly and carrying out orders unquestioningly. Submissiveness as a sign of respect and obedience is a positively valued quality (Morton, 1996) and children's lives should be mo'ui fakongoongo (a life of waiting for instructions). In this way they are told the right things to do, how and when to do them. Obedience to parents is first and foremost but this extends to all other authority within Tongan social hierarchy, including the church. Such submissiveness can be maintained through harsh physical punishment (Kavapalu, 1993) and is an area of direct conflict with Pālangi (European) child-rearing practice and, sometimes, New Zealand laws.

Young New Zealand-born Tongans may not consider fluency in the Tongan language essential to anga faka-Tonga. Seini, when asked whether a person needed to be able to speak Tongan to be Tongan, immediately responded "no." Morton-Lee (2003) concurs, claiming that young people are more willing to allow for the inability to speak the Tongan language. However, as fluency in Tongan language enables understanding of uniquely Tongan concepts, including those encompassed by 'ulungaanga faka-Tonga, it seems to be a key element in defining Tongan identity. Despite Seini's adamant declaration here, she has gone on to study Tongan language at university, perhaps realising that she must be competent in the language to fulfil her ambition of being politically useful to Tongan women. Tongan language conveys knowledge about Tongan people and culture. Language is the paramount vehicle for culture, history and symbolic thought. Māori in New Zealand have realised that without te reo (the Māori language) their culture and their identity as a people would disappear - some Tongans have also come to this conclusion (Taufe'ulungaki, 1993, 2003; Thaman, 1996; Tiatia 1998), considering the situation of New Zealand-born Pasifika young people, reports that a loss of one's language means a loss of culture, thus a displacement of identity.

Fatongi refers to duty. Fatongia involved the serfdom of commoners to chiefs until the 1862 Code of Laws, but now commonly refers to obligations between kin which may involve remittances sent by migrants to family in Tonga. These remittances are generally driven by the concept of fetokoni'aki (helping one another) and are a tangible marker of the love and respect between remitters and recipients. Evans (2001) explains that gift exchange is organised through the concepts of 'ofa (love and generosity), faka'apa'apa (a respectful disposition), and fetokoni'aki all essential elements of the Tongan way. Fetokoni'aki, the quintessential form of generalised reciprocity, is often singled out by Tongans as the defining characteristic of 'ulungaanga faka-Tonga with any and all social ties being best expressed through fetokoni'aki. To practise fetokoni'aki is to show mutual 'ofa sometimes referred to as 'ofa fakaTonga. Gift-giving often involves crops, fish, pigs and other foodstuffs. A family who has provided a feast will redistribute the left-over food (usually plenty) to those who contribute food or labour or attend the feast. During funerals, thousands of dollars worth of food, cash and koloa (treasures, wealth) given to the family of the deceased will be carefully redistributed in accordance with the rank and status of those involved.

'Ofa is a complex, manifestation of the theme of love and the overriding value of Tongan morality - the reason for their behaviour and institutions. It encompasses love, reverence, honour and humbleness (Kavaliku, 1977). Obedience, a sense of duty and reciprocity are all derived from 'ofa. Christianity in Tonga requires faka'apa'apa for God and God gives 'ofa in return (Evans, 2001).

Anga 'ofa (a loving nature), anga faka'apa'apa, mamahi'i me'a (zealousness in a good cause to the point of pain), tauhi vaha'a (maintaining good relations), and lototō (to be humbly willing, deferential but kindly committed) were held up as core values in Tongan culture by Rev. Dr. Asinate F. Samate (2005) in her keynote address to the 11th Tongan History Conference in Melbourne.

The middle ring of Figure 2 shows the cultural expressions of Tonga. The mastery of Tongan dance, the preparation and cooking of traditional foods, the wearing of traditional clothing such as ta'ovala and kiekie, the production of koloa (e.g. mats, tapa etc.) and carvings, the kava (beverage made from crushed roots), the composing of songs and poems, the skill of an orator in the pulpit, fono or feast are the most visible signs of Tongan culture. However, these human cultural expressions are deeply embedded in 'ulungaanga faka-Tonga and while in an isolated context they may still be a thing of beauty, their meaning is diminished without an understanding of their bedrock, the Tongan way. A poto human being needs 'ulungaanga faka-Tonga to bind, shape them 
and define their purpose - to live as an effective person (Evans, 2001) within their environment. To be poto is to be gifted and talented. Gagne's model shows how giftedness is demonstrated as talent. It can therefore also be used to show how a Tongan child develops into a poto and fakapotopoto human being.

\section{The Differentiated Model of Giftedness and Talent}

Gagne's (2008) Differentiated Model of Giftedness and Talent is used extensively throughout the world as a theoretical framework for defining and identifying gifted and talented students. For educators, one advantage of this model over others is in its view of talent as a developmental process to which schools, among many other catalysts, can make positive or negative contributions.

Gagne (2008) provides a useful overview of the model which is summarised here. Firstly, Gagne argues against the prevalent use of 'gifted' and 'talented' as synonyms. He defines the two concepts as follows:

GIFTEDNESS designates the possession and use of outstanding natural abilities, called aptitudes, in at least one ability domain, to a degree that places an individual at least among the top $10 \%$ of age peers.
TALENT designates the outstanding mastery of systematically developed abilities, called competencies (knowledge and skills), in at least one field of human activity to a degree that places an individual at least among the top $10 \%$ of age peers who are or have been active in that field (p. 1).

He then explains that the two concepts share three characteristics: both refer to human activities, both target individuals who differ from the norm/average and both refer to outstanding behaviours. In order to accurately portray the talent development process, the model also incorporates four other concepts - intrapersonal catalysts, environmental catalysts, learning/practice and chance, as shown in Figure 3 below.

The DMGT proposes four aptitude domains of gifts: intellectual, creative, socio-affective and sensorimotor. Each of these can be divided into any number of categories and can be added to or deleted from as research proposes new taxonomies. Without fixed categories, it allows the model to incorporate categories derived from other cultural skill sets. Natural abilities are manifested to varying degrees in the course of all children's development but it is only when the level of expression becomes outstanding that the label 'gifted' can be used. Gagne (2008) maintains high aptitudes/gifts are observed more easily in young

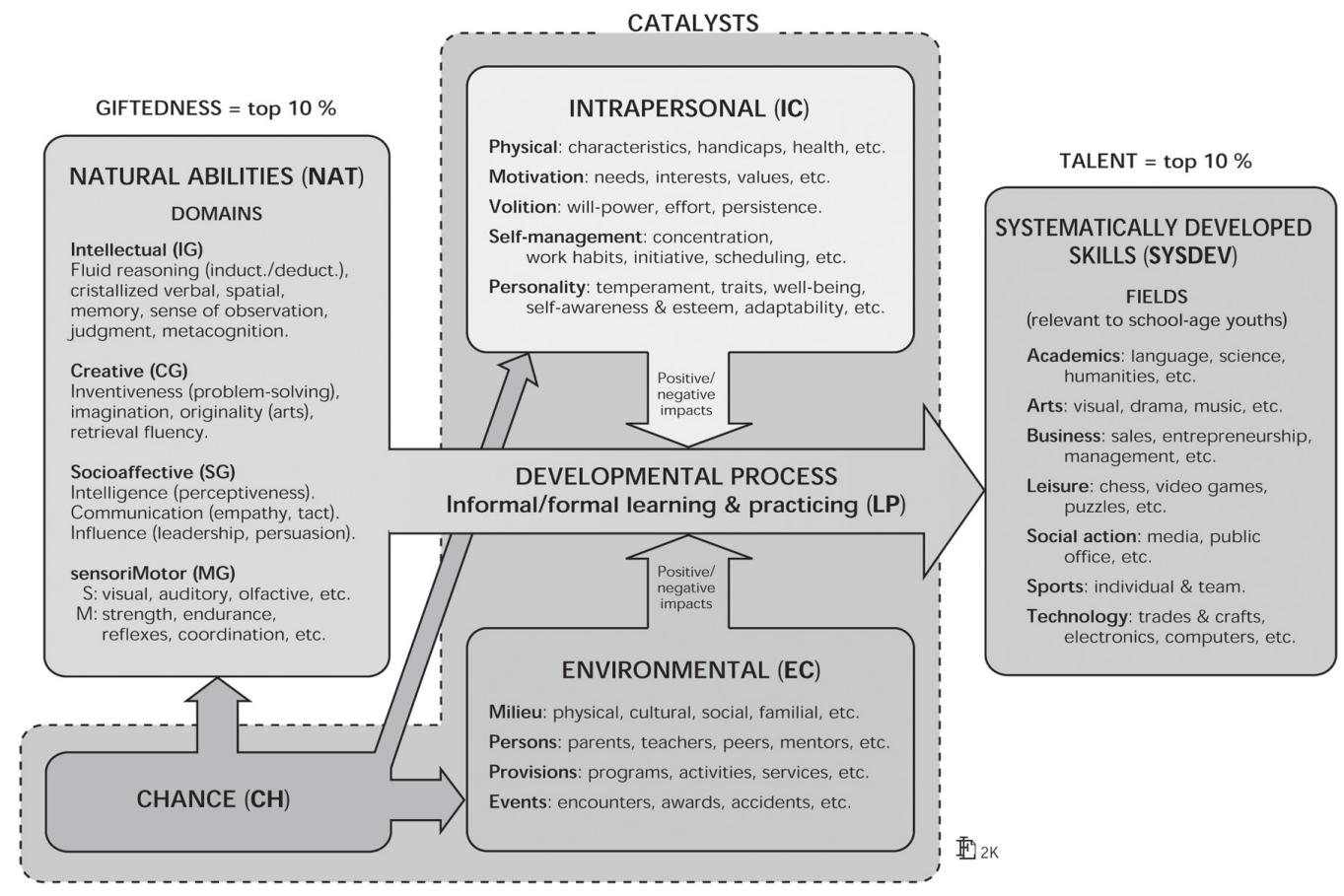

Gagné's Differentiated Model of Giftedness and Talent (DMGT.EN.2K)

Figure 3. The Differentiated Model of Giftedness and Talent. 
children while the influence of environmental factors (which may be negative) is still moderate and largely concern the speed and ease at which they gain skills in a particular domain. This is a good argument for early identification and consultation with parents. Many checklists based on sound research are available to identify the observable behaviours of giftedness. However, some caution needs to be taken to ensure these checklists are culturally-inclusive - an attribute such as 'asks many questions' would not be appropriate to a Tongan child socialised to not interrupt adults. Gagne (2008) points out that psychometrically valid measures of natural abilities have been developed for some domains (e.g., intellectual, muscular, creative, motor control) IQ testing (again, there may be linguistic cultural bias) and fitness testing being considered the most reliable. There are less reliable measures in the other domains (e.g., social, perceptual).

Measuring talent is a straightforward enterprise which corresponds to outstanding performance in the specific skills of any occupational field. During the developmental phase of any talent, normative assessments, such as exams, tests, competitions, and scholarships, present themselves. Beyond the training phase, however, assessments are much less formal and often by word of mouth. In Tongan situations, talent may be 'measured' against cultural parameters such as those involved in becoming poto and the 'assessment' expressed by community experts' approval/disapproval. New Zealand teachers need to develop relationships with such Tongan experts and seek their advice and guidance in order to recognise and develop their students' talent.

Developmental processes can take four different forms - maturation, informal learning, formal non-institutional learning and formal institutional learning. Maturation is a process totally controlled by the genome but can be influenced by factors such as nutrition, disease and exposure to toxins. Informal learning corresponds essentially to knowledge and skills acquired during daily activities. Many of the attributes of a poto Tongan will have been acquired this way. Formal noninstitutional learning corresponds to autodidactic or self-taught learning. For instance, the talent development of accomplished musical performers, The Kami's, a Tongan family in Australia, have followed this process. Ka'ili (2005) reports that this family give credit to God for blessing them with the talent and gift to create and make music because none of the children in the family had received professional lessons in music or in playing any instruments. The most common learning process remains institutionally-based and leads to some form of official recognition of competency: going to school, joining a sports team, enrolling in music lessons or a cooking academy are all examples of formal institutional learning. Many Tongan traditional skills are developed within church contexts which gives them widespread recognition in the Tongan community.

'Catalyst' is a term Gagne (2008) has borrowed from chemistry. A catalyst designates chemical substances introduced into a chemical reaction usually to accelerate it. At the end, these contributors regain their initial state: catalysts contribute to a reaction without being constituents of the final product. In the case of talent development the constituent elements are the natural abilities, which are slowly transformed into specific skills. Talent is strictly measured through the level of skill mastery; neither the type of the contributing catalysts nor the strength of their contribution is relevant to that assessment. The DMGT recognises three types of catalysts: intrapersonal, environmental and chance.

Gagne (2008) divides the intrapersonal catalysts into physical and mental traits, as well as goalmanagement factors. Physical templates, for instance, have been defined for many sports height is advantageous in netball and basketball, strength and muscle mass in the front row of a rugby scrum. Psychological factors are numerous and Gagne admits that the goal management categories created so far - motivation, volition, self-management and personality - may not be exhaustive. These categories are highly influenced by culture.

Environmental factors can have positive or negative impact. Gagne (2008) distinguishes three distinct environmental inputs in the DMGT: milieu, individuals, and provisions. The 'persons' category has, perhaps, created the most controversy with many social scientists, who hold the belief that nurture is a more powerful agent than nature, demonstrating in the literature that significant people in the lives of the gifted and talented can have considerable influence on talent development.

Gagne (2002) credits the first extensive examination of the role of chance in talent development to Abraham Tannenbaum. Gagne (2002) first introduced it into the DMGT among the environmental catalysts but soon realised its influence was greater than that. Most importantly, individuals have no control over their genetic inheritance or the circumstances into which they are born. There is some degree of chance in all the causal components of the model, except the learning and practising process.

Gagne (2008) explains why the ten percent threshold was chosen for the DMGT stressing 
that different reference groups need to be used for identifying gifted individuals and talented individuals. His ten percent avoids restricting giftedness to exceptional giftedness, a rare phenomenon, and includes the "garden variety" of gifted and talented individuals. Pragmatic reasons dictate the use of a fairly broad prevalence estimate to protect those who are gifted and talented from an assumption that, if giftedness is so rare, time and money does not need to be allocated to cater to their special needs.

The relationships among the six elements of the model (gifts, chance, intrapersonal catalysts, environmental catalysts, learning and practising, and talents) are expressed through a complex pattern of interactions. The most fundamental interaction is the causal impact of gifts on talents, gifts being the constituent elements (raw materials) of talent/s, the presence of talent/s implies underlying gift/s. However, the reverse is not true - gifts can remain undeveloped. After consideration of empirical data, Gagne (2002) places the five components of the model in the following decreasing order of causal impact on talent emergence: chance, gifts, intrapersonal, learning/practice, environment. The relative importance of intrapersonal factors - motivation and self- management especially - has implications for teachers of the gifted, and can be culturally influenced. Tongan students can be motivated by fetokoni'aki, the desire to give back to Tongan society and their families.

\section{Personalising the DMGT}

Gagne's DMGT was directly applied to the lives of Seini and Julia, incorporating Tongan elements which clearly show the girls' unique profiles. These profiles were constructed through interviews with them and people significant to them (friends, relations and teachers) whom they nominated. Observations were made of them as they went about their daily lives and their teachers contributed to a survey. The ability of the model to include culturally-specific catalysts is indicative of its flexibility and cultural validity. All of the elements of the model can be interpreted through different cultural lenses and it is for this reason this model was used to investigate gifted and talented Tongan individuals.

Figures 4 and 5, shown below, are visual representations of Seini's and Julia's processes of talent development, highlighting the catalysts for transforming their gifts. Seini was able to convert her gifts of metacognition, fluid reasoning, verbal memory, imagination, originality, communication and influence to cultural, academic, and sporting leadership roles. Despite lacking knowledge of faka-Tonga, other cultural qualities and Tongan ways of being acted as catalysts for her cultural talents.

As the model shows for Julia (Figure 5), her gifts of verbal memory, perception, intelligence, communication, influence and sensorimotor

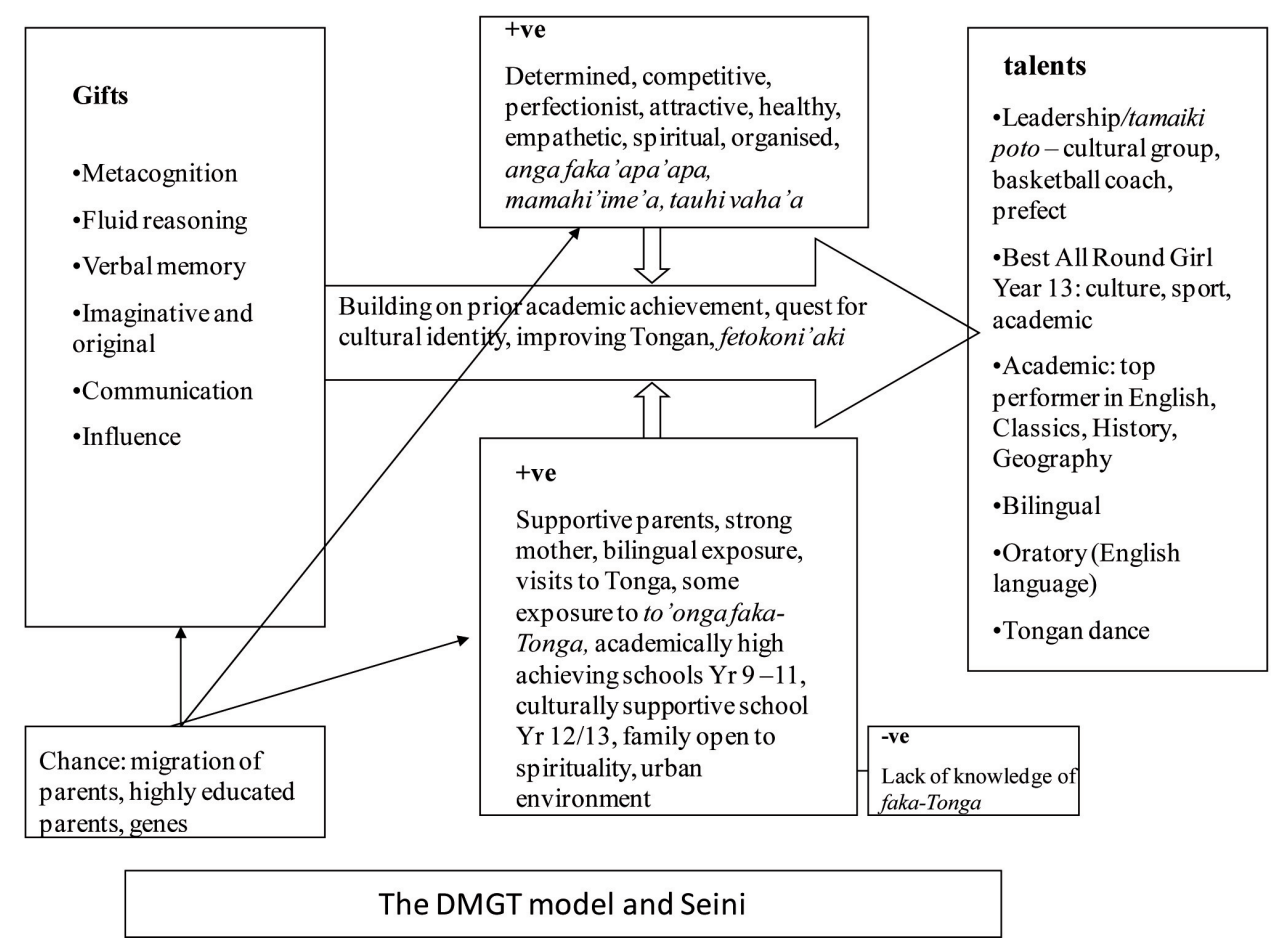

Figure 4. The DMGT model and Seini. 


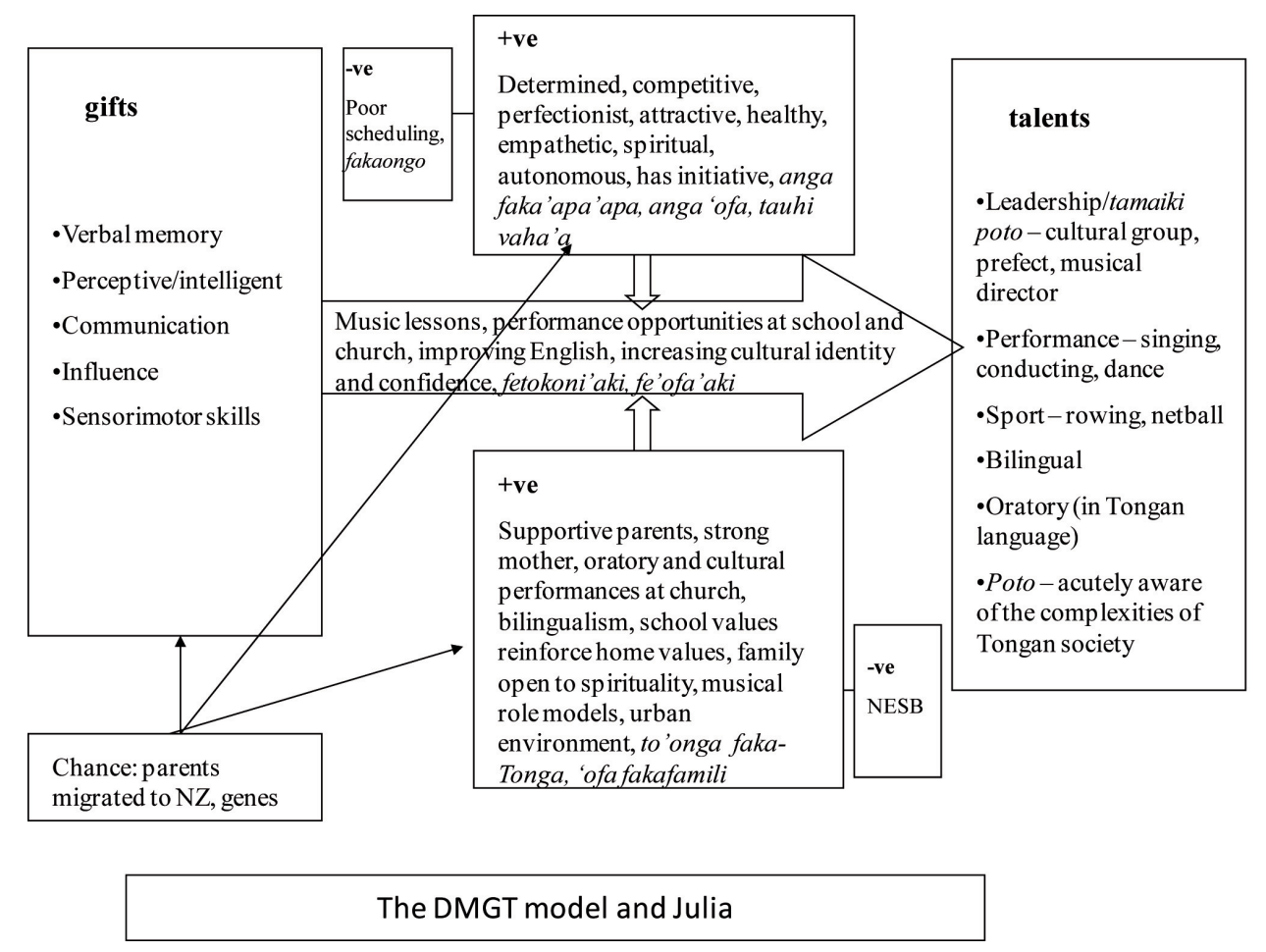

Figure 5. The DMGT model and Julia.

skills were developed through music lessons, performance opportunities at church and school, English language development, and cultural identity. Julia's talents of leadership, performance, and sport are both generic and culturally-specific. Julia demonstrated poto through her acute awareness of the complexities of Tongan society. For both gifted young women, the impact of chance played a role in how their cultural abilities and qualities have been applied and developed: as children of migrants into New Zealand, their environment and the aspirations of their parents have had an influence.

Julia and Seini were both jusitified in being nominated as "gifted and talented" students. However, their schools contributed to their talent development in a fairly ad hoc way; the Deputy Principal at Seini's school noted that this was more by default than design. In the DMGT, formal schooling fits best as an environmental catalyst although it can contribute to intrapersonal catalysts by influencing such factors as motivation and self-management. The schools were not neighbourhood schools for the girls and their parents deliberately chose schools that best fitted with their family values. These values in both families included elements of 'ulungaanga fakaTonga (the Tongan way). For Julia, 'ulungaanga faka-Tonga was the basis of family life whereas Seini's family were much more assimilated into pālangi lifestyle and western ways. She has, as Tiatia (1998) has identified, the unique identity of the New Zealand-born which requires that they need to construct for themselves a paradigm that is uniquely their own to grant them empowerment of voice and a visible presence. In order to give a more Tongan shape to this paradigm, Seini's parents elected to send her to a school where Tongan culture was an integral part of school life in a deliberate effort to improve her knowledge of Tongan language and 'ulungaanga faka-Tonga. For both girls their culture became more important as they developed their adolescent identities.

There is growing recognition of the importance of understanding Pasifika perspectives of giftedness and talent, but there is very little information (based on practice, theory or research) to help teachers unpack those perspectives. As a minority population, it is likely that Pasifika students have been under-represented in programmes and provisions for gifted and talented students. How can the under-representation of our Pasifika students be addressed without a wide base of research and practice to help unpack and explain their unique cultural perspectives? One approach is to work with parents, families, communities, and gifted and talented Pasifika students to explore broader concepts of giftedness and talent. Gagne's model can serve as a framework for analysing gifts and their realisation as talents based on catalysts, chance, and processes of development. New Zealand teachers need to consider how they contribute to the 'design' of talent development. The default position does not always enable Pasifika students to achieve the hopes and aspirations of their communities, families and themselves. 


\section{REFERENCES}

Evans, M. (2001). Persistence of the gift: Tongan tradition in transnational context. Waterloo, Ontario: Wilfred Laurier University Press.

Frengley-Vaipuna, I. (2007). Creating Kakala: Gifted and talented Tongan students in New Zealand secondary schools. A thesis presented in partial fulfilment of the requirements for the degree of M.Ed. Massey University, New Zealand.

Gagne, F. (2002). Understanding the complex choreography of talent development through DMGT-based analysis. In K. A. Heller, F. J. Monks, R. J. Sternberg and R. F. Subotnik (Eds.), International Handbook of Giftedness and Talent 2nd Edition (Revised Reprint), (pp. 67-79). Oxford, Elsevier Science Ltd.

Gagne, F. (2008). Building gifts into talents: Brief overview of the DMGT 2.0. Retrieved on September 18, 2011 from http://www. giftedconference2009.org/presenter_files/gagne_ p12_therealnature.pdf

Helu, I. F. (1999a). Traditional custom and good governance. Critical essays: Cultural perspectives from the South Seas. Canberra: Australian National University.

Helu, I. F. (1999b). The ethnoscience of the cultivation of the frail kahokaho. Critical essays: Cultural perspectives from the South Seas. I. F. Helu. Canberra: Australian National University.

Helu, I. F. (1999c). Cultural survival. Critical sssays: Cultural perspectives from the South Seas. Canberra: Australian National University.

Ka'ili, A. (2005). Exclusive interview with The Kamis Family, Planet Tonga. Retrieved on September 16, 2011, from http://www.planet-tnga.com/

Kavaliku, S. L. (1977). 'Ofa! The treasure of Tonga. Pacific Perspective, 66(2): 47-67.

Kavapalu, H. (1993). Dealing with the dark side in the ethnography of child punishment in Tonga. Oceania, 63(4): 313-329.

Morton, H. (1996). Becoming Tongan: An ethnography of childhood. Honolulu: University of Hawai'i Press.

Morton-Lee, H. (2003). Tongans overseas: Between two shores. Honolulu: University of Hawai'i Press.

Samate, A. F. (2005). Understanding Tongans involves the heart as well as the mind. 11th Tonga History Conference, Melbourne. Retrieved on September 16, 2011, from http://groups.yahoo.com/group/ tonga/message/8400>

Statistics, N.Z. (2006). Tongan people in New Zealand. Retrieved on September 16, 2011, from http://www.stats.govt.nz/census/about-2006census/pacific-profiles-2006.aspx
Taufe'ulungaki, A. M. (1993). “Tongan language community attitudes and their implications for the continuing maintenance and promotion of the Tongan language." TESOLANZ Journal, 1: 67-87.

Taufe'ulungaki, A. M. (2003). Vernacular languages and classroom interactions in the Pacific. In K. H. Thaman (Ed.), Educational ideas from Oceania. Fiji, Institute of Education and UNESCO Chair of Teacher Education and Culture. Suva, Fiji: University of the South Pacific.

Tau'akipulu, L.B.J. (2000). Individualism and community: A case study of Tongan identity in Aotearoa New Zealand, and its social and political implications. Unpublished Masters thesis, University of Auckland.

Thaman, K. H. (1996). Reclaiming an education: Culture, teaching and learning. National Symposium. Retrieved on September 16, 2011 from http://www.voced.edu.au/content/ngv40543

Thompson, O.R.R. (1992). The student's TonganEnglish dictionary. Nuku'alofa: Friendly Islands Bookshop.

Tiatia, J. (1998). Caught between cultures: A New Zealand-born Pacific Island perspective. Auckland: Christian Research Association.

\section{AUTHORS' PROFILES}

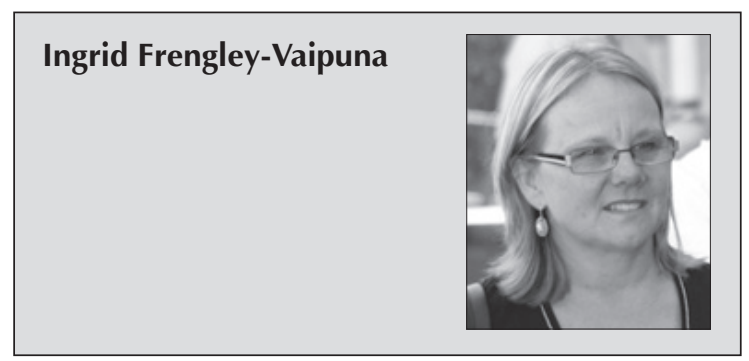

Ingrid Frengley-Vaipuna has spent 30 years teaching (mostly English) in Australia, Tonga and New Zealand and is currently Deputy Principal at Patea Area School in South Taranaki. She has recently moved onto a small lifestyle block in Patea and is putting a lifelong interest in ensuring a sustainable future into practice. She has always been interested in the education of gifted students and completed a MEd thesis titled Creating Kakala: Gifted and Talented Tongan Secondary School Students in New Zealand in 2007. She worked for Massey University as an adviser in Gifted and Talented education 2007-2008. She is married to Paul Vaipuna, is the mother of four adult and teenaged children, and Oma to four grandchildren who reflect the ethnically diverse family theme: one Māori, one Tongan and Australian twins!

EMAIL

vaipunain@pateaarea.school.nz 


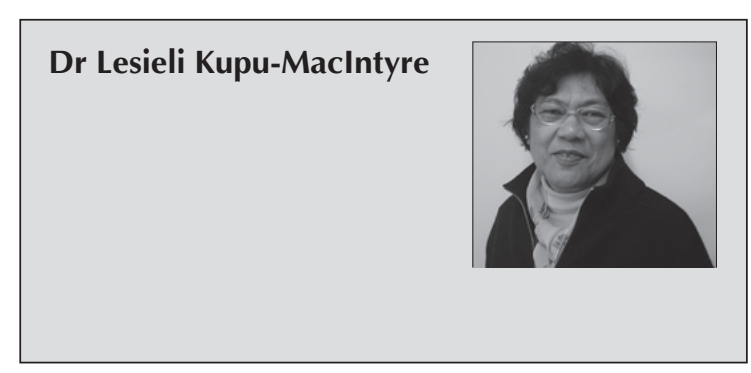

Dr Lesieli Kupu-MacIntyre is a Senior Lecturer in the School of Educational Studies at Massey University College of Education. She has taught at primary, secondary, and tertiary levels in Tonga and in New Zealand; she currently holds a New Zealand Teacher Registration Certificate. Before coming to Massey, Lesieli was a Tongan Language and Cross cultural trainer for the US Peace Corps/Tonga. She currently teaches papers on Pasifika Education and another on Teaching of Pasifika students in New Zealand. She supervises postgraduate students undertaking research on various aspects of Pasifika Education, including Giftedness and Talent in the classroom. Lesieli sits on a number of advisory committees and writing teams for the Ministry of Education, Learning Media, and NZQA. In her spare time, she writes stories to support Pasifika children's learning in New Zealand.

EMAIL

I.i.macintyre@massey.ac.nz

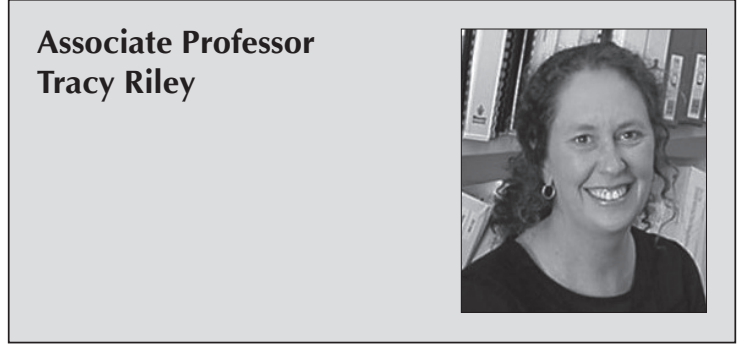

Associate Professor Tracy Riley specialises in gifted and talented education at Massey University. She teaches undergraduate and postgraduate papers in the field, as well as supervision of postgraduate research. Tracy is the co-editor of APEX: The NZ Journal of Gifted Education. An active advocate for gifted and talented students, Tracy has served on numerous Ministry of Education advisory groups and co-authored the Ministry handbook, Gifted and Talented Students: Meeting Their Needs in New Zealand Schools. In 2007, Tracy was awarded the Vice-Chancellor's Award for Sustained Excellence in Teaching and was a recipient of a national Tertiary Teaching Excellence Award. Tracy is a member of the Executive Committee of the Ako Aoteoroa Academy of Tertiary Teaching Excellent, Chairperson of the Board of giftEDnz, The Professional Association for Gifted Education, and a Trustee for the Gifted Children's Advancement Charitable Trust.

EMAIL

T.L.Riley@massey.ac.nz 